\title{
Growth and mortality rates of Prochlorococcus and Synechococcus measured with a selective inhibitor technique
}

\author{
Hongbin Liu, Lisa Campbell, Michael R. Landry \\ Department of Oceanography, School of Ocean and Earth Science and Technology, University of Hawaii, Honolulu, \\ Hawaii 96822, USA
}

\begin{abstract}
A selective metabolic inhibitor method has been developed to estimate growth rates and mortalities due to protozoan grazing of the photoautotrophic prokaryotic picoplankton Prochlorococcus and Synechococcus. Laboratory and field experiments show that $1 \mathrm{mg} \mathrm{ml}^{-1}$ (final concentration) kanamycin inhibits the growth of Prochlorococcus and Synechococcus effectively and does not significantly affect protozoan grazing. At Station ALOHA $\left(22^{\circ} 45^{\prime} \mathrm{N}, 158^{\circ} \mathrm{W}\right) 100 \mathrm{~km}$ north of Oahu, Hawaii, USA, growth rates of Prochlorococcus ranged from 0.4 to $0.5 \mathrm{~d}^{-1}$ within the surface mixed layer to about $0.1 \mathrm{~d}^{-1}$ at the bottom of the euphotic zone. Synechococcus grew faster, with a daily growth rate of up to $1.0 \mathrm{~d}^{-1}$ in surface waters. Grazing mortalities varied for Prochlorococcus and Synechococcus from 20 to $116 \%$ and 43 to $87 \%$ of growth rates, respectively. Growth generally exceeded grazing. Because of its high abundance (up to $2 \times 10^{5}$ cells $\mathrm{ml}^{-1}$ in the upper $100 \mathrm{~m}$ ), Prochlorococcus contributes significantly to phytoplankton biomass and primary production in the subtropical North Pacific Ocean. At Station ALOHA in October 1993, integrated $(0$ to $175 \mathrm{~m})$ carbon production due to Prochlorococcus was $382.2 \mathrm{mg} \mathrm{C} \mathrm{m}^{-2} \mathrm{~d}^{-1}$. In contrast, Synechococcus produced only $14.6 \mathrm{mg} \mathrm{C} \mathrm{m}^{-2} \mathrm{~d}^{-1}$.
\end{abstract}

KEY WORDS: Growth · Mortality $\cdot$ Prochlorococcus $\cdot$ Synechococcus $\cdot$ Selective inhibitor $\cdot$ FLB

\section{INTRODUCTION}

Within the last decade, photosynthetic picoplankton $(<2 \mu \mathrm{m}$ cells) have been found to account for more than half of the biomass and primary production in the tropical and subtropical open ocean (Li et al. 1983, Platt et al. 1983, Takahashi \& Bienfang 1983, Herbland et al. 1985). Among them, 2 groups of prokaryotic cells, Synechococcus and Prochlorococcus, were reported to be the predominant components in this size class. The phycoerythrin-containing unicellular cyanobacteria Synechococcus were the first to be studied in detail because they are easily recognized by their distinctive orange fluorescence under the epifluorescence microscope (Johnson \& Sieburth 1979, Waterbury et al. 1979, Olson et al. 1990a). Early studies reported that Synechococcus contributed up to $95 \%$ of total primary production (Glover 1985, Iturriaga \& Mitchell 1986, Waterbury et al. 1986, Iturriaga \& Marra 1988). However, as we now realize, the pres- ence of Prochlorococcus confounded these estimates. Prochlorococcus, a new group of oxyphototrophic marine prokaryotes containing divinyl chlorophylls $a$ and $b$, were discovered in the mid-1980s by Chisholm et al. (1988) using flow cytometry. Prochlorococcus is now recognized as a major component of the picoplankton in warm oceanic waters of the Atlantic Ocean (Li \& Wood 1988, Olson et al. 1990), the Pacific Ocean (Chavez et al. 1991, Campbell \& Vaulot 1993), as well as the Mediterranean (Vaulot et al. 1990) and Red Seas (Veldhuis \& Kraay 1993). The relative importance of Prochlorococcus and Synechococcus to the total photosynthetic biomass varies among oceanic regions. While Synechococcus contributes only $2 \%$ of particulate organic carbon (POC) in the central North Pacific, Prochlorococcus contributes up to $30 \%$ of POC in the upper $200 \mathrm{~m}$ water column (Campbell et al. 1994). In the northern Indian Ocean, Synechococcus accounts for up to $40 \%$ of the POC (Burkill et al. 1993). However, because of the overlap 
in cell size between Prochlorococcus and Synechococcus, the contribution of either individual group to total primary production cannot be obtained accurately by size-fractionated photosynthetic measurements.

The growth rate of Synechococcus has been studied quite intensively (Landry et al. 1984, Campbell \& Carpenter 1986a, b, Iturriaga \& Mitchell 1986, Iturriaga \& Marra 1988, Burkill et al. 1993). In contrast, there are only a few recent reports of the growth rates of Prochlorococcus (Goericke \& Welschmeyer 1993, Vaulot et al. 1994). There are many indirect and direct methods to estimate a population's growth rate (see review by Furnas 1990). Because of grazing, the change in cell abundance in the water column reveals the net growth rate. The dilution method (Landry \& Hassett 1982, Landry et al. 1984) and selective metabolic inhibition (Newell et al. 1983, Fuhrman \& McManus 1984) techniques are the 2 most frequently used methods to estimate grazing mortalities and compute absolute growth rates of phytoplankton.

The use of selective metabolic inhibitors in the study of marine phytoplankton was first reported for eukaryotes (Thomas \& Dodson 1974). Newell et al. (1983), for example, applied the eukaryotic inhibitors cycloheximide and thiram to estimate grazing rates on bacteria. Fuhrman \& McManus (1984) modified this method by using benzylpenicillin as a prokaryotic inhibitor for estimating rates of bacterivory in Long Island Sound (New York, USA). Sherr et al. (1986) compared the eukaryotic inhibitors (cycloheximide + colchicine) and prokaryotic inhibitors (vancomycin + penicillin) in the study of trophic interactions between heterotrophic protozoa and bacterioplankton in estuarine waters. Ampicillin, a prokayotic inhibitor, has also been used to estimate the growth rate of and grazing pressure on Synechococcus (Campbell \& Carpenter 1986b). However, none of the above have proved satisfactory for Prochlorococcus (M. R. Landry unpubl.). Through a series of laboratory and field tests, we found that kanamycin is an effective growth inhibitor for both Prochlorococcus and Synechococcus. Kanamycin inhibits protein synthesis by combining with the ribosomes to disrupt the genetic code and induce the production of mutant forms (Pelczar et al. 1977). The formation of faulty membrane-associated proteins renders the membrane leaky, causing the loss of essential small molecules and enhanced uptake of more kanamycin, which is then sufficient to prevent further protein synthesis (Greenwood 1989). The key problem in using the selective metabolic inhibitor approach is the specificity of the inhibitor. Therefore, we advocate the addition of fluorescently labeled bacteria (FLB) as an internal control in all incubations to test this critical assumption. We report preliminary results of the kanamycin method for estimating growth rates and grazing mortality of Prochlorococcus and Synechococcus populations.

\section{MATERIALS AND METHODS}

Culture. Prochlorococcus and Synechococcus strains were isolated from Station ALOHA, located about $100 \mathrm{~km}$ north of Oahu, Hawaii, USA, in the central Pacific Ocean $\left(22^{\circ} 45^{\prime} \mathrm{N}, 158^{\circ} \mathrm{W}\right)$. Prochlorococcus was cultured in PC media (modified $\mathrm{K} / 2$ ) as recommended by the Culture Collection of Marine Plankton at Bigelow Laboratory (West Boothbay Harbor, ME, USA). Synechococcus was grown in f/2 media. Neither Prochlorococcus nor Synechococcus cultures are axenic. All culture containers were carefully cleaned by first soaking in $10 \%$ hydrochloric acid $(\mathrm{HCl})$ for at least $24 \mathrm{~h}$. The containers were then rinsed with distilled deionized water (DDW) several times, soaked in DDW for more than $24 \mathrm{~h}$, rinsed several times, and autoclaved at $121^{\circ} \mathrm{C}$ for $20 \mathrm{~min}$.

Laboratory experiments. Kanamycin stock solutions (10 to $100 \mathrm{mg} \mathrm{ml}^{-1}$ ) were made immediately prior to use by dissolving kanamycin (Sigma, K-4000) in DDW and filter sterilizing (Acrodisc $0.2 \mu \mathrm{m}$ syringe filters).

To determine the kanamycin concentration required to inhibit growth without causing cell lysis or death, we performed growth experiments with final kanamycin concentrations of $0,0.01,0.10,0.50$ and $1.0 \mathrm{mg} \mathrm{ml}^{-1}$. Triplicate cultures of Prochlorococcus and Synechococcus were grown in $20 \mathrm{ml}$ glass test tubes under continuous illumination of approximately $20 \mu \mathrm{Ein} \mathrm{m}^{-2} \mathrm{~s}^{-1}$. Samples $(0.5 \mathrm{ml})$ were taken at $6 \mathrm{~h}$ intervals from each test tube using sterile technique, preserved with paraformaldehyde $(0.2 \%$ final concentration), frozen quickly in liquid nitrogen, and stored at $-80^{\circ} \mathrm{C}$. Thawed samples were analyzed by flow cytometry following the method of Vaulot et al. (1989).

To test whether kanamycin affected the grazing activity of protozoans, 2 enrichment cultures, a heterotrophic nanoflagellate (HNAN) and a mixture of nanoflagellates and ciliates from Kaneohe Bay (KEW), were grown in rice culture media with $0,0.1$ and $1.0 \mathrm{mg} \mathrm{ml}^{-1}$ kanamycin. FLB were made from Vibrio damsela with 5-([4,6-dichlorotriazin-2-yl]amino)-fluorescein (DTAF) following the procedure of Sherr et al. (1987), and were added to triplicate experimental tubes at a final concentration of $20000 \mathrm{ml}^{-1}$. Samples $(0.5 \mathrm{ml})$ were taken every $6 \mathrm{~h}$ for flow cytometric determination of FLB abundance. Grazing rates were computed from the rate of decline of FLB concentration with time.

Field experiments. Field experiments were conducted in Kaneohe Bay, Hawaii, during February 1993 and at the Hawaii Ocean Time-series (HOT) Station ALOHA in 
May, September and October 1993. As described below, some details varied among experiments. Similarities included incubations of triplicate $250 \mathrm{ml}$ polycarborate bottles for each treatment and control. In addition, FLB were added to all bottles at a final concentration of 10000 cells ml ${ }^{-1}$ to test whether the kanamycin inhibited grazing activity and/or to correct for an inhibitor effect on grazing if it occurred. For individual experiments, we used the difference between FLB disappearance rates in the incubation treatments and controls to compute inhibitor-corrected growth and grazing rates for Prochlorococcus and Synechococcus. In most cases, we observed a small effect of kanamycin on grazing activity based on the difference in FLB disappearance rates between treatments. The difference was most often statistically insignificant due to a large standard deviation and small sample number (see Table 1). We did, however, correct our grazing and growth rates because of the apparent effect.

Initial experiments in Kaneohe Bay were conducted to verify the effective kanamycin concentration for natural populations. Seawater samples were collected before dawn from the sea surface inside and from adjacent oceanic waters outside the bay. Kanamycin was added to the bottles to yield final concentrations of 0 (control), $0.01,0.1$ and $1.0 \mathrm{mg} \mathrm{ml}^{-1}$. All bottles were incubated in situ in surface waters near Coconut Island in Kaneohe Bay for $24 \mathrm{~h}$. A $1 \mathrm{ml}$ subsample was taken from each bottle every $6 \mathrm{~h}$ using the same procedure described for laboratory experiments.

For experiments at Station ALOHA, Go-Flo bottles were used to collect seawater before sunrise from 5,45 and $100 \mathrm{~m}$ in May and 75 and $125 \mathrm{~m}$ in September. Based on results from Kaneohe Bay, only 1 kanamycin concentration $\left(1 \mathrm{mg} \mathrm{ml}^{-1}\right)$ and a control were prepared. Triplicate bottles for the treatment and control were incubated in a shipboard temperature- and lightcontrolled incubator, and an additional set of triplicate samples was incubated in situ in order to compare the 2 incubation techniques. The in situ incubation lasted between dawn and dusk, and subsamples for flow cytometric analyses were taken at the beginning and end of the experiment. Subsamples were taken every $6 \mathrm{~h}$ during the $24 \mathrm{~h}$ shipboard incubations.

For the October experiment, seawater was collected from 8 depths from 5 to $175 \mathrm{~m}$. The incubation procedure was also modified because previous results revealed that cell division of Prochlorococcus occurred more during nighttime and, therefore, that dawn-todusk incubations underestimated specific growth rates. Triplicate bottles were incubated in situ from dawn-to-dusk followed by shipboard incubation after dark to complete a $24 \mathrm{~h}$ incubation.

Flow cytometry. All samples were analyzed using a Coulter EPICS 753 flow cytometer equipped with two
5 W Argon lasers and MSDS automatic sampling. Filter set-ups were as previously described by Campbell \& Vaulot (1993). For Prochlorococcus and Synechococcus, we used an excitation wavelength of $488 \mathrm{~nm}(1 \mathrm{~W})$ to collect green ( $525 \mathrm{~nm} \pm 40 \mathrm{df})$, orange ( $575 \mathrm{~nm} \pm$ $40 \mathrm{df})$ and red ( $680 \mathrm{~nm} \pm 40 \mathrm{df})$ fluorescence and right angle light scatter (RALS), which varies as a function of cell size. Sample volumes were $100 \mu \mathrm{l}$ for most analyses, however, 200 to $300 \mu \mathrm{l}$ were analyzed for some samples to obtain a statistically significant cell number for Synechococcus. Prochlorococcus and Synechococcus populations were distinguished from heterotrophic bacteria by their respective red (divinyl chlorophyll) and orange (phycobilin) autofluorescences under $488 \mathrm{~nm}$ excitation. FLB were characterized by bright green fluorescence. In laboratory experiments, subsamples for enumeration of heterotrophic bacteria were stained with $1 \mu \mathrm{g} \mathrm{ml}^{-1}$ Hoechst 33342 (Molecular Probes, Eugene, OR, USA) and analyzed with dual UV/488 nm excitation (Monger \& Landry 1993). Heterotrophic bacteria have blue fluorescence under UV excitation (DNA content) but lack any autofluorescence. List mode files were analyzed on an IBM PCcompatible microcomputer using CytoPC software (Vaulot 1989).

Calculations. Instantaneous rates of population growth and grazing mortality were calculated for Prochlorococcus and Synechococcus as described by Campbell \& Carpenter (1986b). Protozoan grazing on FLB in all experiments were determined from the same exponential model. Integrated growth rates $\left(\mathrm{d}^{-1}\right)$ in the upper $175 \mathrm{~m}$ water column are calculated from:

$$
\mu_{\text {int }}=\ln \left[\int \mathrm{N}_{24}(z) \mathrm{d} z / \int \mathrm{N}_{0}(z) \mathrm{d} z\right]
$$

where $\mathrm{N}_{0}$ is cell abundance at the beginning time of incubation, $\mathrm{N}_{24}$ is cell abundance after the $24 \mathrm{~h}$ incubation without accounting for grazing (i.e. $\mathrm{N}_{24}=\mathrm{N}_{0} \mathrm{e}^{\mu}$ ), and $z$ is the sampling depth. For the experiments at Station ALOHA, carbon production of Prochlorococcus and Synechococcus were calculated from cell abundance, growth rates and a carbon/cell conversion factor and compared with total primary production measured by ${ }^{14} \mathrm{C}$ method (data provided by Joint Global Ocean Flux Study). We assumed conversion factors of 53 and $250 \mathrm{fg} \mathrm{C} \mathrm{cell}^{-1}$ for Prochlorococcus and Synechococcus, respectively (Campbell et al. 1994). Carbon production $\left(P, \mathrm{mg} \mathrm{C} \mathrm{m}^{-3} \mathrm{~d}^{-1}\right)$ at each sampling depth was calculated as:

$$
P=N \times \mathrm{fgC} \mathrm{cell}^{-1} \times 10^{-6}
$$

where $N\left(\right.$ cell ml $\left.{ }^{-1} \mathrm{~d}^{-1}\right)$ is the number of cells produced in $24 \mathrm{~h}$ which can be computed from

$$
N=N_{0}\left(\mathrm{e}^{\mu}-1\right) .
$$




\section{RESULTS}

\section{Laboratory experiments}

Laboratory incubations with different concentrations of kanamycin indicated that concentrations of 1 and $0.5 \mathrm{mg} \mathrm{ml}^{-1}$ prevented cell division of Prochlorococcus and Synechococcus, respectively (Fig. 1). Kanamycin had no effect on the growth of heterotrophic bacteria co-occurring in the cultures of laboratory experiments. Grazing experiments showed no statistically significant difference in protozoan grazing on FLB between the control and kanamycin treatments (Fig. 2) (ANOVA: $F=2.13, \mathrm{p}=0.234, \mathrm{df}=2$ for HNAN; $F=0.86$, $p=0.469, \mathrm{df}=2$ for KEW). We chose a kanamycin concentration of $1 \mathrm{mg} \mathrm{ml}^{-1}$ for all subsequent field experiments.
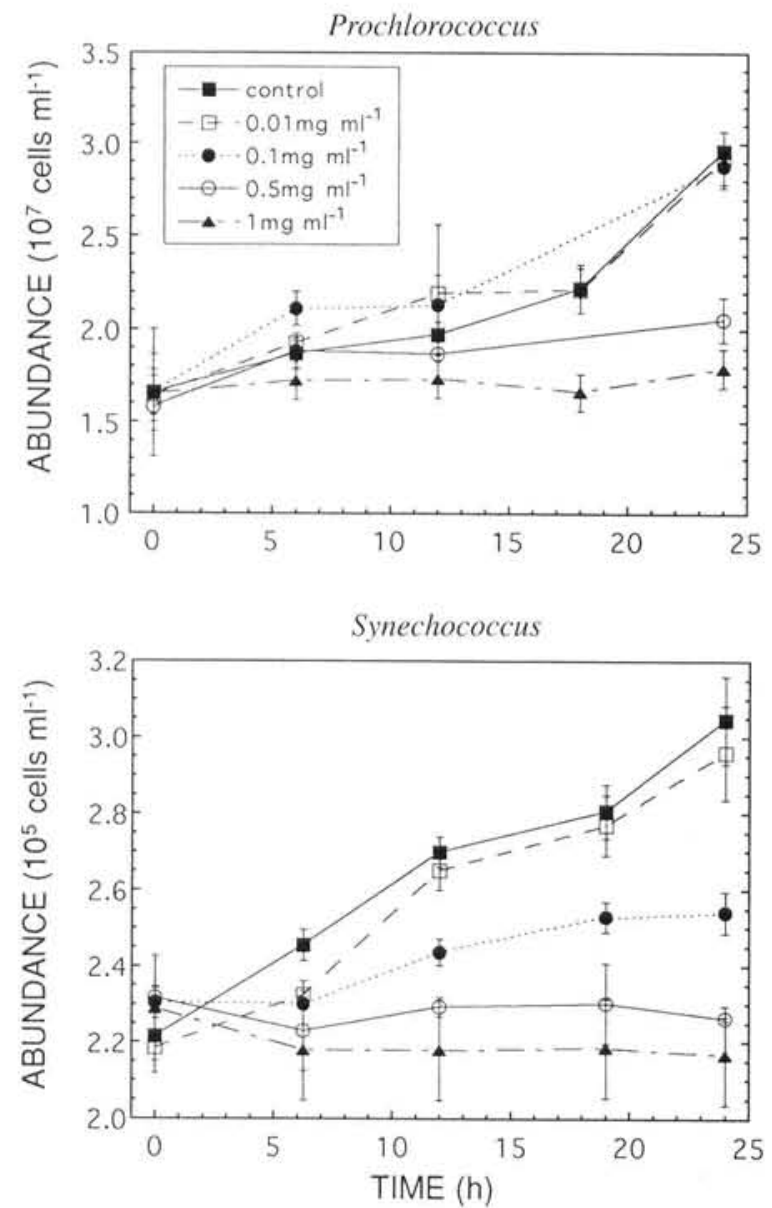

Fig. 1. Prochlorococcus (Pacific strain) and Synechococcus. Laboratory experiments with different concentrations of kanamycin under continuous light. For Synechococcus, curves of control and $0.5 \mathrm{mg}$ kanamycin $\mathrm{ml}^{-1}$ (final concentration) are significantly different ( $t$-test, $p<0.005)$. For Prochlorococcus, $1 \mathrm{mg}$ kanamycin $\mathrm{ml}^{-1}$ prevents cell division $(t$-test, $\mathrm{p}<0.0025)$. Error bars show $1 \mathrm{SD}$ of the means of triplicate incubations

\section{Kaneohe Bay field studies}

The results of the Kaneohe Bay experiments showed a slight decrease of protozoan grazing on FLB in samples with $1 \mathrm{mg} \mathrm{ml}^{-1}$ of kanamycin, but no significant difference from controls (Table 1, Fig. 3b, c). The slower decrease of Prochlorococcus abundance in the $1 \mathrm{mg} \mathrm{ml}^{-1}$ kanamycin incubations than in other treatments also suggests that protozoan grazing activity was affected, in particular during the first few hours after adding kanamycin to incubations (Fig. 3a). However, this grazing inhibition during the first $6 \mathrm{~h}$ was not observed clearly for Synechococcus (Fig. 3d, e).

The growth rates of Synechococcus measured in Kaneohe Bay and in oceanic waters were similar, 0.70 and $0.58 \mathrm{~d}^{-1}$, respectively. Prochlorococcus growth rate was substantially lower, $0.33 \mathrm{~d}^{-1}$ for oceanic waters. Prochlorococcus were not observed inside Kaneohe Bay. The daily grazing mortality of Prochlorococcus and Synechococcus calculated from $24 \mathrm{~h}$ in situ incubations revealed that only about $30 \%$ of the pro-
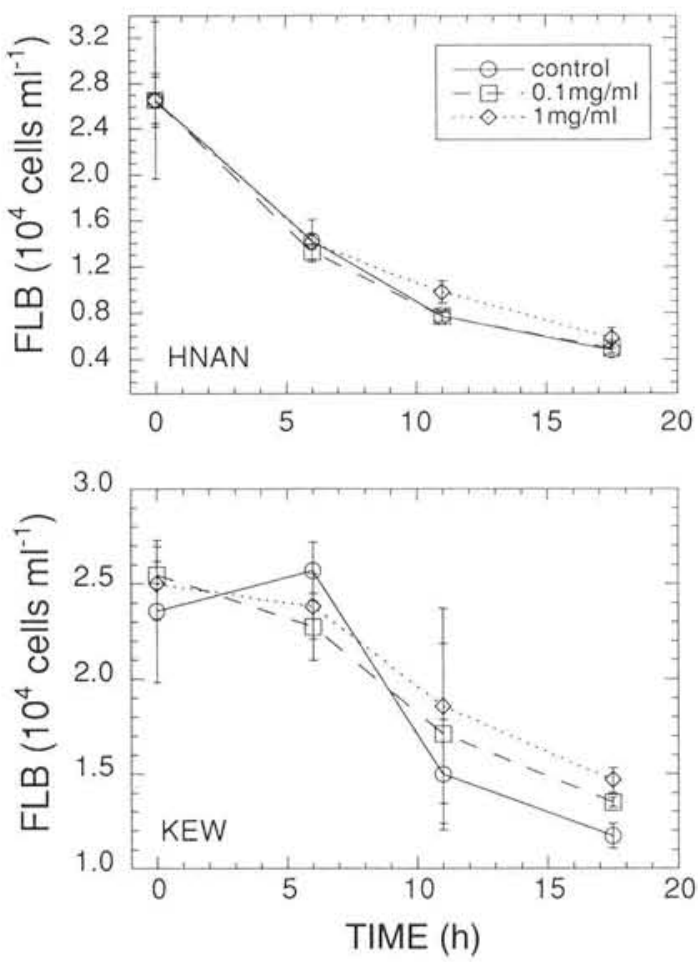

Fig. 2. Results of laboratory experiments to test the effect of kanamycin on protozoan grazing. Data show no difference of protozoan grazing on fluorescently labeled bacteria (FLB) between treatments. HNAN: a culture of a heterotrophic nanoflagellate (ANOVA, $F=2.13, \mathrm{p}=0.234$, df $=2$ ); KEW: a mixture of nanoflagellates and ciliates (ANOVA, $F=0.86, p=$ $0.469, \mathrm{df}=2$ ). Error bars show $1 \mathrm{SD}$ of the means of triplicate incubations 
Table 1. The difference in protozoan grazing on FLB in the control and inhibitor (1 $\mathrm{mg} \mathrm{ml}^{-1}$ kanamycin) incubations tested by $t$-test. Data are the means of triplicate measurements $\pm 1 \mathrm{SD}$ calculated from $24 \mathrm{~h}$ incubations. In the May 1993 experiment, rates from dawn-to-dusk incubation are given in parentheses. ${ }^{\circ} \mathrm{p}<0.05$; ns: $\mathrm{p}>0.05$

\begin{tabular}{|c|c|c|c|}
\hline \multirow{2}{*}{$\begin{array}{r}\text { Location } \\
\text { Depth }\end{array}$} & \multicolumn{2}{|c|}{ Grazing rates on FLB $\left(\mathrm{d}^{-1}\right)$} & \multirow[t]{2}{*}{$t$-test } \\
\hline & Control & Inhibitor & \\
\hline \multicolumn{4}{|l|}{ Kaneohe Bay } \\
\hline Bay, surface & $0.47 \pm 0.07$ & $0.35 \pm 0.10$ & $1.70 \mathrm{~ns}$ \\
\hline Oceanic, surface & $0.51 \pm 0.06$ & $0.39 \pm 0.07$ & $2.25 \mathrm{~ns}$ \\
\hline \multicolumn{4}{|l|}{ Station ALOHA } \\
\hline \multicolumn{4}{|l|}{ May 1993} \\
\hline $5 \mathrm{~m}$ & $\begin{array}{c}0.30 \pm 0.10 \\
(0.62 \pm 0.10)\end{array}$ & $\begin{array}{c}0.27 \pm 0.10 \\
(0.60 \pm 0.01)\end{array}$ & $\begin{array}{c}0.37 \mathrm{~ns} \\
(0.34) \mathrm{ns}\end{array}$ \\
\hline $45 \mathrm{~m}$ & $\begin{aligned} 0.38 & \pm 0.03 \\
(0.67 & \pm 0.05)\end{aligned}$ & $\begin{array}{c}0.29 \pm 0.14 \\
(0.50 \pm 0.28)\end{array}$ & $\begin{array}{l}1.09 \mathrm{~ns} \\
(1.04) \mathrm{ns}\end{array}$ \\
\hline $100 \mathrm{~m}$ & $\begin{array}{c}0.30 \pm 0.07 \\
(0.17 \pm 0.02)\end{array}$ & $\begin{array}{l}0.32 \pm 0.07 \\
0.08 \pm 0.00\end{array}$ & $\begin{array}{l}0.35 \mathrm{~ns} \\
(6.33)^{\circ}\end{array}$ \\
\hline \multicolumn{4}{|l|}{ October 1993} \\
\hline $5 \mathrm{~m}$ & $0.49 \pm 0.14$ & $0.29 \pm 0.24$ & $1.25 \mathrm{~ns}$ \\
\hline $25 \mathrm{~m}$ & $0.33 \pm 0.02$ & $0.26 \pm 0.10$ & $1.19 \mathrm{~ns}$ \\
\hline $45 \mathrm{~m}$ & $0.17 \pm 0.13$ & $0.14 \pm 0.04$ & $0.38 \mathrm{~ns}$ \\
\hline $75 \mathrm{~m}$ & $0.10 \pm 0.07$ & $0.13 \pm 0.02$ & $0.71 \mathrm{~ns}$ \\
\hline $100 \mathrm{~m}$ & $0.20 \pm 0.09$ & $0.18 \pm 0.14$ & $0.21 \mathrm{~ns}$ \\
\hline $125 \mathrm{~m}$ & $0.21 \pm 0.08$ & $0.12 \pm 0.10$ & $1.22 \mathrm{~ns}$ \\
\hline $150 \mathrm{~m}$ & $0.08 \pm 0.04$ & $0.09 \pm 0.05$ & $0.27 \mathrm{~ns}$ \\
\hline $175 \mathrm{~m}$ & $0.13 \pm 0.04$ & $0.09 \pm 0.11$ & $0.59 \mathrm{~ns}$ \\
\hline Overall ( $\mathrm{n}=40)$ & $0.32 \pm 0.18$ & $0.25 \pm 0.18$ & $1.66 \mathrm{~ns}$ \\
\hline
\end{tabular}

$0.05 \mathrm{~d}^{-1}$ at $75 \mathrm{~m}$ in September) because cell division of Prochlorococcus occurs at a higher rate during the night (Fig. 5). In October, a higher Prochlorococcus growth rate of $0.59 \mathrm{~d}^{-1}(\mathrm{SE}=0.09)$ was found at $25 \mathrm{~m}$. Again, the growth rates of Prochlorococcus were lowest at $75 \mathrm{~m}\left(0.09 \mathrm{~d}^{-1}\right)$ and increased slightly below (Table 2, Fig. 7).

Synechococcus grew faster than Prochlorococcus, with growth rates ranging from 0.39 to $0.70 \mathrm{~d}^{-1}$ throughout the upper $100 \mathrm{~m}$ water column during May and September (Table 2). In contrast, during October Synechococcus growth rate was much higher $\left(1.06 \mathrm{~d}^{-1}\right.$, $\mathrm{SE}=0.09$ ) near the sea surface but decreased to $0.17 \mathrm{~d}^{-1}(\mathrm{SE}=0.04)$ at $75 \mathrm{~m}$ (Table 2, Fig. 7). The integrated growth rates in the upper $175 \mathrm{~m}$ water column are $0.26 \mathrm{~d}^{-1}$ for Prochlorococcus and $0.44 \mathrm{~d}^{-1}$ for Synechococcus.

Mortality rates of Prochlorococcus measured in $24 \mathrm{~h}$ incubations at Station ALOHA ranged from 0.04 to $0.50 \mathrm{~d}^{-1}$ within the upper $175 \mathrm{~m}$ water column (Table 2). The ratio of grazing to growth estimates ranged from 0.20 to 1.16. Grazing on Synechococcus seemed less variable with grazing to growth ratios of 0.43 to 0.87 . Grazing mortality (especially for Prochlorococcus), measured in in situ dawn-to-dusk incubations, was higher than in $24 \mathrm{~h}$ incubations and always resulted in negative net growth rates for Prochlorococcus. Grazing of FLB showed the same pattern duction of Prochlorococcus in the surface water was lost to grazing. In comparison, the grazing pressure on Synechococcus spp. at both sites was 38 to $56 \%$ of its daily growth (Table 2).

\section{Station ALOHA field studies}

Results from $24 \mathrm{~h}$ deck incubations during the first experiment (May 1993; Figs. 4 to 6 ) indicated that Prochlorococcus grows slowly under oligotrophic conditions. Calculated growth rates averaged $0.20( \pm 0.03) \mathrm{d}^{-1}$ at $45 \mathrm{~m}$ and 0.10 $( \pm 0.09) \mathrm{d}^{-1}$ at $100 \mathrm{~m}$. Growth rates of Prochlorococcus in the September experiments were similar with higher rates measured at $125 \mathrm{~m}\left(0.17 \pm 0.06 \mathrm{~d}^{-1}\right)$ than at $75 \mathrm{~m}\left(0.09 \pm 0.01 \mathrm{~d}^{-1}\right)$. The growth rates of Prochlorococcus calculated from dawn-to-dusk (i.e. 12 to $14 \mathrm{~h}$ ) in situ incubations in these experiments were lower $\left(0.09 \pm 0.06 \mathrm{~d}^{-1}\right.$ at $45 \mathrm{~m}$ and $0.04 \pm$ $0.01 \mathrm{~d}^{-1}$ at $100 \mathrm{~m}$ in May, and $0.05 \pm$
Table 2. Prochlorococcus and Synechococcus. Grazing rates $(g)$ and growth coefficients $(\mu)$ in Kaneohe Bay and at Station ALOHA measured by selective inhibitor method. Data are the means of triplicate $24 \mathrm{~h}$ incubations $\pm 1 \mathrm{SD}$

\begin{tabular}{|ccccc|}
\hline \multirow{2}{*}{$\begin{array}{c}\text { Location } \\
\text { Depth }\end{array}$} & \multicolumn{2}{c}{ Prochlorococcus } & \multicolumn{2}{c|}{ Synechococcus } \\
& $\mu\left(\mathrm{d}^{-1}\right)$ & $g\left(\mathrm{~d}^{-1}\right)$ & $\mu\left(\mathrm{d}^{-1}\right)$ & $g\left(\mathrm{~d}^{-1}\right)$ \\
\hline $\begin{array}{l}\text { Kaneohe Bay } \\
\text { Inside, surface }\end{array}$ & & & & \\
Outside, surface & $0.33 \pm 0.02$ & $0.10 \pm 0.02$ & $0.58 \pm 0.04$ & $0.39 \pm 0.05$ \\
& & & & $0.22 \pm 0.07$ \\
Station ALOHA & & & & \\
May 1993 & & & $0.54 \pm 0.08$ & $0.29 \pm 0.14$ \\
$5 \mathrm{~m}$ & & & & \\
$45 \mathrm{~m}$ & $0.20 \pm 0.03$ & $0.04 \pm 0.02$ & $0.44 \pm 0.11$ & $0.26 \pm 0.10$ \\
$100 \mathrm{~m}$ & $0.10 \pm 0.09$ & $0.09 \pm 0.06$ & $0.58 \pm 0.09$ & $0.46 \pm 0.01$ \\
September 1993 & & & & \\
$75 \mathrm{~m}$ & $0.09 \pm 0.01$ & $0.10 \pm 0.06$ & $0.39 \pm 0.22$ & $0.27 \pm 0.02$ \\
$125 \mathrm{~m}$ & $0.17 \pm 0.06$ & $0.12 \pm 0.08$ & & \\
October 1993 & & & & \\
$5 \mathrm{~m}$ & $0.38 \pm 0.10$ & $0.44 \pm 0.01$ & $1.06 \pm 0.18$ & 0.73 \\
$25 \mathrm{~m}$ & $0.59 \pm 0.19$ & $0.50 \pm 0.16$ & $0.45 \pm 0.30$ & $0.39 \pm 0.18$ \\
$45 \mathrm{~m}$ & $0.10 \pm 0.03$ & $0.06 \pm 0.03$ & $0.67 \pm 0.31$ & $0.47 \pm 0.06$ \\
$75 \mathrm{~m}$ & $0.09 \pm 0.02$ & $0.05 \pm 0.06$ & $0.17 \pm 0.13$ & $0.09 \pm 0.08$ \\
$100 \mathrm{~m}$ & $0.15 \pm 0.14$ & $0.14 \pm 0.18$ & & \\
$125 \mathrm{~m}$ & $0.13 \pm 0.05$ & $0.14 \pm 0.07$ & & \\
$150 \mathrm{~m}$ & $0.11 \pm 0.10$ & $0.06 \pm 0.02$ & & \\
$175 \mathrm{~m}$ & $0.21 \pm 0.11$ & $0.14 \pm 0.02$ & & \\
& & & & \\
\hline
\end{tabular}



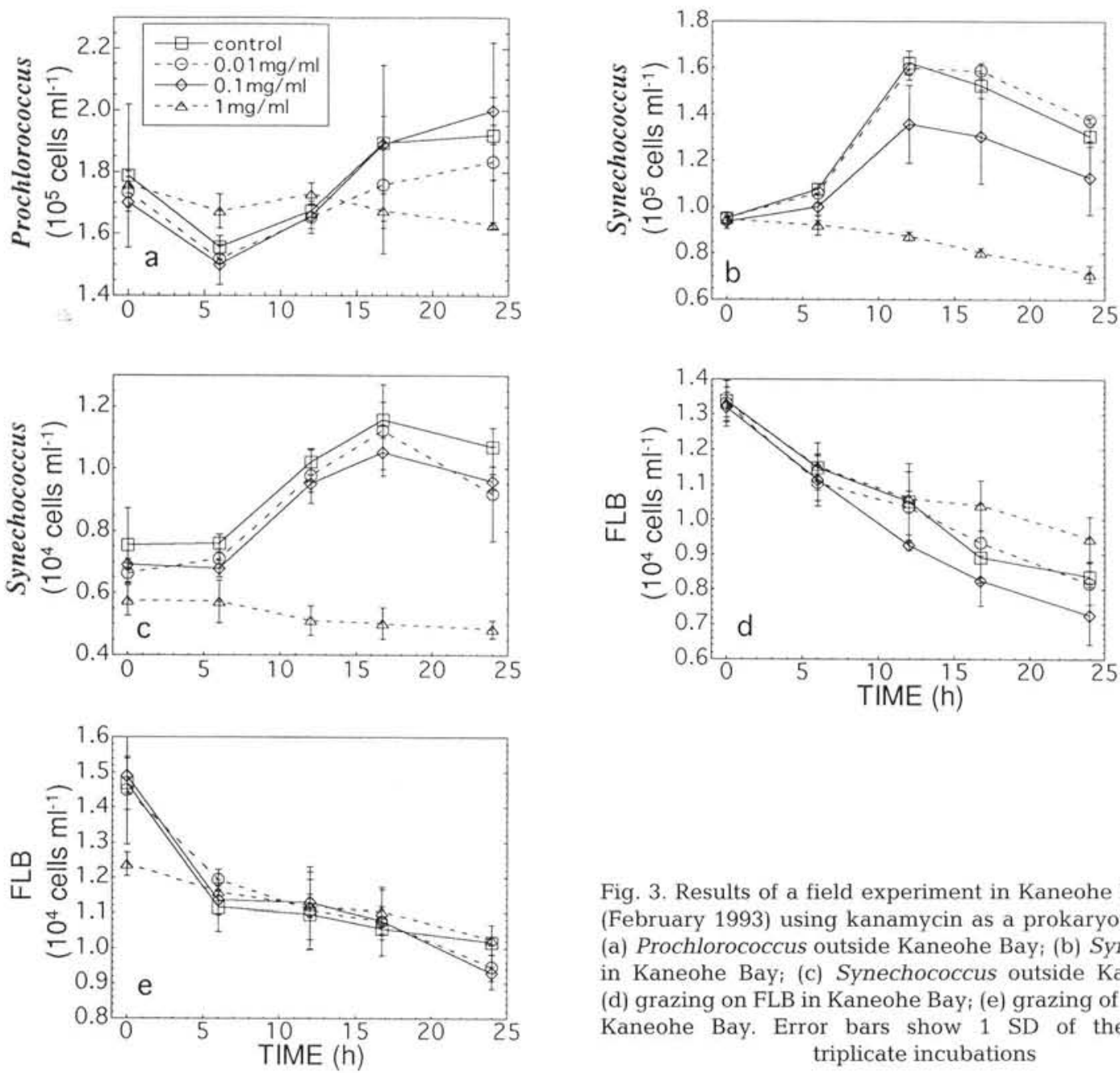

Fig. 3. Results of a field experiment in Kaneohe Bay, Hawaii (February 1993) using kanamycin as a prokaryotic inhibitor. (a) Prochlorococcus outside Kaneohe Bay; (b) Synechococcus in Kaneohe Bay; (c) Synechococcus outside Kaneohe Bay; (d) grazing on FLB in Kaneohe Bay; (e) grazing of FLB outside Kaneohe Bay. Error bars show 1 SD of the means of triplicate incubations

which probably implies higher grazing activities of protozoans during the daylight hours (Table 2). Overall, the growth rates and grazing mortalities of both Prochlorococcus and Synechococcus showed the similar trend with depth, but growth exceeded grazing in most cases (Table 2, Fig. 7).

An alternative way of estimating the contribution of both groups to total primary production is to determine specific growth rates of Prochlorococcus and Synechococcus and convert to carbon production with carbon/cell conversion factors. The calculated carbon production of Prochlorococcus at Station ALOHA ranged from $10.05 \mathrm{mg} \mathrm{C} \mathrm{m}^{-3} \mathrm{~d}^{-1}$ in surface water to $0.04 \mathrm{mg} \mathrm{C}$ $\mathrm{m}^{-3} \mathrm{~d}^{-1}$ at the bottom of the euphotic zone (Table 3, Fig. 7). It is interesting to note that Prochlorococcus contributed the most to production in the surface waters and at $125 \mathrm{~m}$ (Table 3). Synechococcus was only detected in the upper $100 \mathrm{~m}$ of the water column and accounted for less than $5 \%$ of the total primary production (Table 3, Fig. 7b).

\section{DISCUSSION}

Selective metabolic inhibitors have several advantages for estimating the growth rates of the marine photosynthetic picoplankton Prochlorococcus and Synechococcus and their mortality due to grazing activities of heterotrophic nanoplankton. These include minimal manipulation of seawater samples, no radioisotopes, and the ability to measure simultaneously growth and grazing for natural bacterial plankton populations (Campbell \& Carpenter 1986b, Sherr et al. 1986). The application of the specific inhibitor methods depends on both the effectiveness and specificity of the inhibitor. In our experiments, $1 \mathrm{mg} \mathrm{ml}^{-1}$ kanamycin successfully inhibits cell division of Prochlorococcus and Synechococcus. However, it also seems to exert a minor effect on the grazing activity of protozoans (see Table 2). Although this effect was not statistically significant in our experiments, it is essential to include the FLB control in all grazing experi- 
ments. One possible impact of the inhibition of protozoan activity is a decrease in growth rates of Prochlorococcus and Synechococcus due to a decrease in the availability of remineralized nitrogen or phosphorus during the incubations. Another potential artifact is an alteration of the physiological status of prokaryotic picoplankton. We found that the chlorophyll fluorescence of Prochlorococcus in the surface mixed layer samples in some cases decreased after incubation with the addition of kanamycin. This may have been due to an effect of kanamycin on chlorophyll synthesis or turnover rate.

Our results suggest that a $24 \mathrm{~h}$ incubation period is critical for obtaining an unbiased growth rate because of diel cycles of DNA synthesis and growth in Synechococcus (Campbell \& Carpenter 1986a, Waterbury et
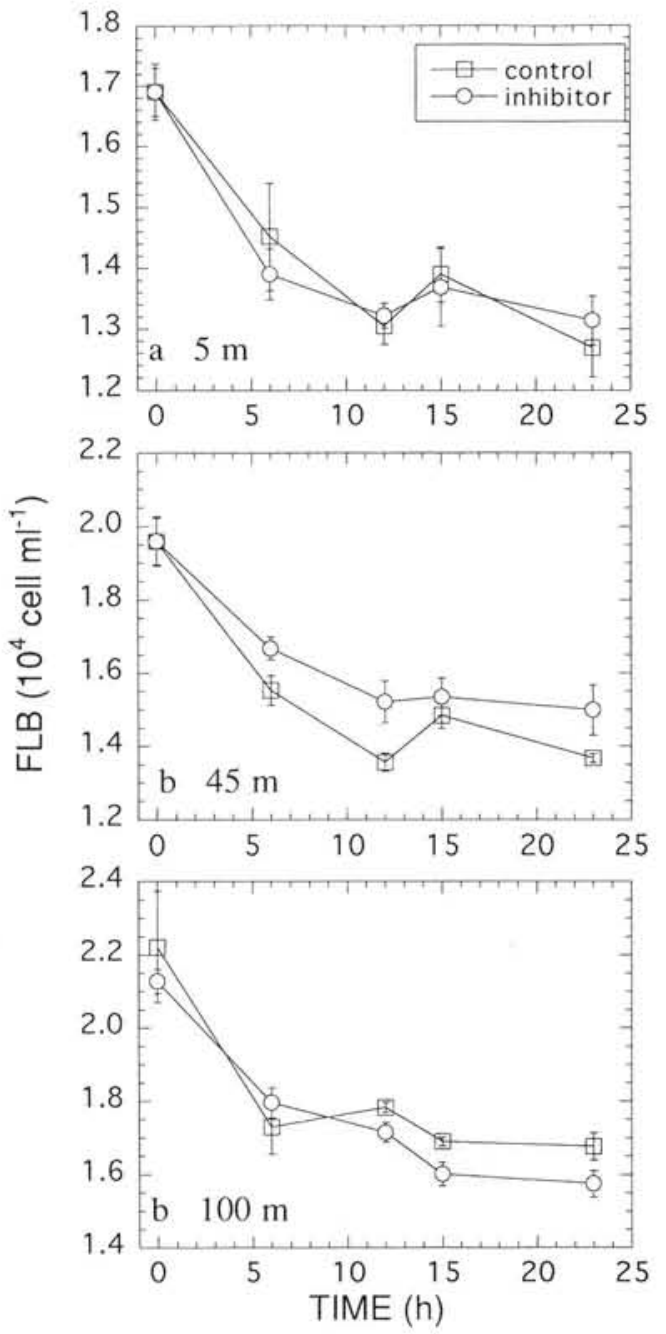

Fig. 4. Changes in the density of FLB in $24 \mathrm{~h}$ shipboard incubations at Station ALOHA in May 1993. Error bars show 1 SE of the means of triplicate incubations. Control: natural seawater; inhibitor: $1 \mathrm{mg} \mathrm{ml}^{-1}$ kanamycin (final concentration)

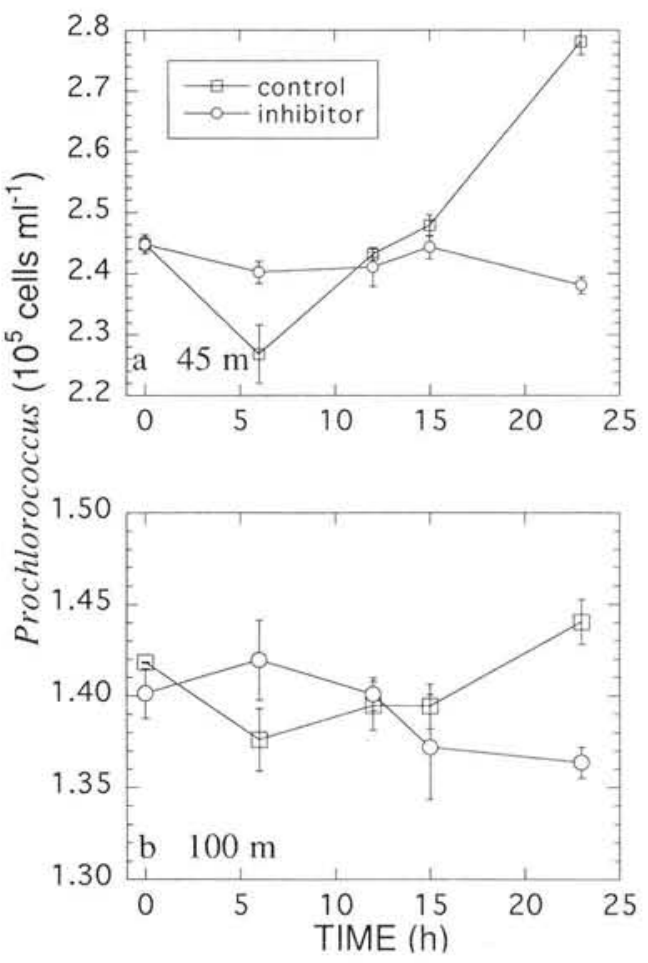

Fig. 5. Prochlorococcus. Changes in density in $24 \mathrm{~h}$ shipboard incubations at Station ALOHA in May 1993. Error bars show $1 \mathrm{SE}$ of the means of triplicate incubations. Control: natural seawater; inhibitor: $1 \mathrm{mg} \mathrm{ml}^{-1}$ kanamycin

al. 1986, Armbrust et al, 1989) and Prochlorococcus (Vaulot et al. 1994). The highest division rates of Synechococcus were realized in early evening, i.e. 12 to $15 \mathrm{~h}$ after dawn (Campbell \& Carpenter 1986a), whereas Prochlorococcus started cell division after sunset (Vaulot et al. 1994). Therefore, dawn-to-dusk incubations underestimate the 'true' daily growth rate, especially for Prochlorococcus.

Our results show that average daily growth rates for Prochlorococcus range from 0.4 to $0.6 \mathrm{~d}^{-1}$ in near-surface waters and 0.1 to $0.2 \mathrm{~d}^{-1}$ at the base of the euphotic zone. Our estimates are close to the observations of Goericke \& Welschmeyer (1993) for Prochlorococcus in the Sargasso Sea near Bermuda using the ${ }^{14} \mathrm{C}$ labeling technique. However, they are lower than the observation of Vaulot et al. (1994) for the equatorial Pacific (0.52 to $0.65 \mathrm{~d}^{-1}$ integrated for upper $150 \mathrm{~m}$ ) based on cell cycle analysis (Carpenter \& Chang 1988). The growth rate of Synechococcus measured in Kaneohe Bay ( 0.58 to $0.70 \mathrm{~d}^{-1}$ ) and at Station ALOHA $\left(0.17\right.$ to $\left.1.06 \mathrm{~d}^{-1}\right)$ are lower than those measured in previous studies in the same bay (Landry et al. 1984) and in the oligotrophic North Pacific (Iturriaga \& Mitchell 1986), but similar to the rates measured in the northwest Atlantic Ocean (Campbell \& Carpenter 1986b) and the northwest Indian Ocean (Burkill et al. 1993). 

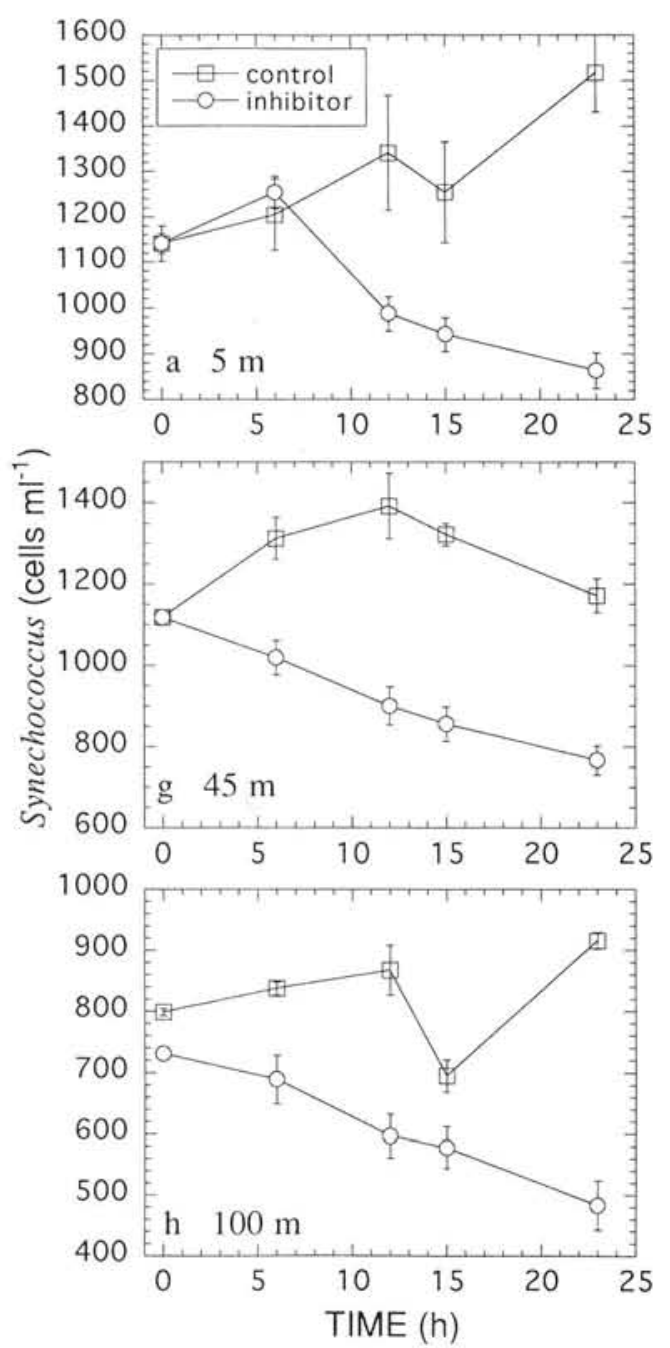

Fig. 6. Synechococcus. Changes in density in $24 \mathrm{~h}$ shipboard incubations at Station ALOHA in May 1993. Error bars show $1 \mathrm{SE}$ of the means of triplicate incubations. Control: natural seawater; inhibitor: $1 \mathrm{mg} \mathrm{ml}^{-1}$ kanamycin

The trophic interactions between heterotrophic nanoplankton and bacterioplankton in the open ocean are one of the key links of the microbial loop (Azam et al. 1983). Heterotrophic flagellates and ciliates are thought to be the major grazers of picoplankton, including heterotrophic bacteria, Prochlorococcus, Synechococcus and picoeukaryotes (Sieburth 1984). Our estimates of grazing pressure on Synechococcus in Kaneohe Bay $\left(0.22\right.$ to $\left.0.39 \mathrm{~d}^{-1}\right)$ and at Station ALOHA ( 0.09 to $\left.0.73 \mathrm{~d}^{-1}\right)$ are in close agreement with previous reports (Landry et al. 1984, Campbell \& Carpenter 1986b, Iturriaga \& Mitchell 1986). The estimates of grazing mortality on Synechococcus ranged from 43 to $87 \%$ of growth rate. The grazing rate on Prochlorococcus observed outside Kaneohe Bay and in $24 \mathrm{~h}$ incubations at Station ALOHA are more variable (20 to
$>100 \%$ of the estimated growth rates). The parity of growth and grazing rates for both Prochlorococcus and Synechococcus indicates that they are significant components of the marine pelagic food web and that most of their biomass is recycled fairly rapidly within the euphotic zone. Standard productivity experiments, such as post-incubation size-fractionated ${ }^{14} \mathrm{C}$ experiments, may underestimate production of picoplankton because heterotrophic nanoplankton are not eliminated by pre-screening samples before incubation. Also, calculating carbon production from net growth rate (growth - grazing; Veldhuis et al. 1993) will greatly underestimate the production of Prochlorococcus and Synechococcus.

One interesting phenomenon is the negative growth rate of Prochlorococcus observed in most dawn-todusk incubations. This trend could be explained by either a diel cycle in cell growth or heavier grazing during daytime. Our data show that grazing on FLB is more intense in dawn-to-dusk in situ incubations than in the $24 \mathrm{~h}$ shipboard incubation (Table 1). The disappearance of FLB in $24 \mathrm{~h}$ incubations (Fig. 4) was also faster during daytime. Whether this is attributable to the existence of a diel cycle in grazing activity or an increase in the abundance of heterotrophic nanoplankton needs further investigation. Based on the diel cycle of growth and grazing of Prochlorococcus and

Table 3. Prochlorococcus and Synechococcus. Total primary production and the production contributed in the upper $175 \mathrm{~m}$ water column at Station ALOHA. Total primary production as measured by the ${ }^{14} \mathrm{C}$ uptake method; data courtesy of Tupas et al. (1994). Production values of Prochlorococcus and Synechococcus are calculated from growth rate measurements (see text for details). Integrated: from surface to $175 \mathrm{~m}$ (October 1993 only) ( $\left.\mathrm{mg} \mathrm{C} \mathrm{m}^{-2} \mathrm{~d}^{-1}\right)$

\begin{tabular}{|c|c|c|c|}
\hline \multirow[t]{2}{*}{ Depth } & \multicolumn{3}{|c|}{ Carbon production (mg C m${ }^{-3} \mathrm{~d}^{-1}$ ) } \\
\hline & Total & Prochlorococcus & Synechococcus \\
\hline \multicolumn{4}{|l|}{ May 1993} \\
\hline $5 \mathrm{~m}$ & 9.07 & & 0.20 \\
\hline $45 \mathrm{~m}$ & 8.25 & 2.87 & 0.16 \\
\hline $100 \mathrm{~m}$ & 3.05 & 0.78 & 0.15 \\
\hline \multicolumn{4}{|c|}{ September 1993} \\
\hline $75 \mathrm{~m}$ & 3.81 & 1.05 & 0.19 \\
\hline $125 \mathrm{~m}$ & 0.60 & 0.64 & \\
\hline \multicolumn{4}{|c|}{ October 1993} \\
\hline $5 \mathrm{~m}$ & 4.61 & 5.88 & 0.29 \\
\hline $25 \mathrm{~m}$ & 3.29 & 10.05 & 0.15 \\
\hline $45 \mathrm{~m}$ & 2.22 & 1.36 & 0.18 \\
\hline $75 \mathrm{~m}$ & 1.51 & 1.25 & 0.09 \\
\hline $100 \mathrm{~m}$ & 1.16 & 0.62 & 0.01 \\
\hline $125 \mathrm{~m}$ & 0.29 & 0.27 & \\
\hline $150 \mathrm{~m}$ & 0.11 & 0.06 & \\
\hline $175 \mathrm{~m}$ & 0.05 & 0.04 & \\
\hline Integrated & 274 & 382.2 & 14.6 \\
\hline
\end{tabular}



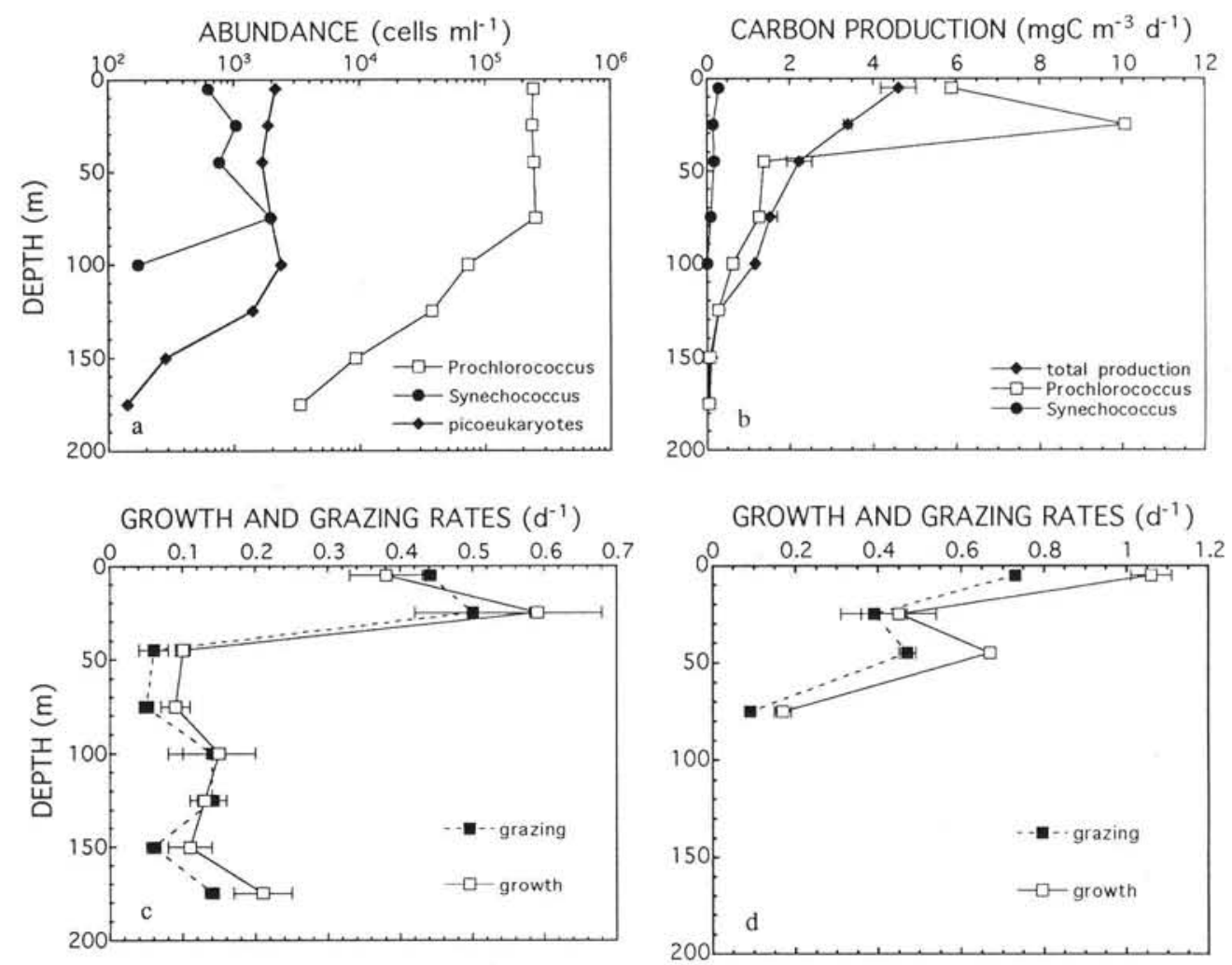

Fig. 7. Depth profile of upper $200 \mathrm{~m}$ water column at Station ALOHA in October 1993. (a) Vertical distribution of Prochlorococcus, Synechococcus and picoeukaryotes. Data are the means of samples at the start point. (b) Carbon production at different depths; total production was measured by the ${ }^{14} \mathrm{C}$ method (see Tupas et al. 1994) and production of Prochlorococcus and Synechococcus is calculated from growth rates (Table 2). (c) Growth rates and grazing mortalities of Prochlorococcus measured by selective inhibitor method in dawn-to-dusk in situ incubations followed by dark deck incubations (means \pm SE). (d) Growth and grazing rates of Synechococcus measured in the same experiment

Synechococcus, dawn-to-dusk in situ incubations are inappropriate for estimating daily growth and grazing rates. Dawn-to-dusk in situ incubations followed by shipboard incubations during the dark period gave reasonable results in our October experiments at Station ALOHA.

Prochlorococcus is extremely important at Station ALOHA in terms of cell abundance and carbon biomass in comparison to the Atlantic and Indian Oceans. On the average, Prochlorococcus spp. represent $64 \%$ of the total photosynthetic carbon biomass in the upper $200 \mathrm{~m}$ at Station ALOHA (Campbell et al. 1994). The percentages of Prochlorococcus to the total photosynthetic carbon biomass in the surface mixed layer, deep chlorophyll maximum, and $<0.05 \% I_{0}$ (generally 150 to $170 \mathrm{~m}$ ) are $73 \%, 47 \%$ and $33 \%$, respectively. Our data show that Prochlorococcus also contributes significantly to primary production at Station ALOHA, but there is temporal variation between cruises (Table 3, Fig. 7). We cannot calculate the exact percentages of Prochlorococcus and Synechococcus contributions to total primary production because our estimations are not comparable to the total primary production measured by ${ }^{14} \mathrm{C}$ method. Our calculation is closer to the gross production, whereas the ${ }^{14} \mathrm{C}$ method does not include carbon uptake that is subsequently ingested by protozoa and lost to respiration and DOC release. In October 1993, the integrated primary production due to Prochlorococcus in the upper $175 \mathrm{~m}$ at Station ALOHA was $382.2 \mathrm{mg} \mathrm{C} \mathrm{m}^{-2} \mathrm{~d}^{-1}$, which exceeds the integrated total primary production measured by the ${ }^{14} \mathrm{C}$ method $\left(274 \mathrm{mg} \mathrm{C} \mathrm{m}^{-2} \mathrm{~d}^{-1}\right)$. Nevertheless, this result indicates that Prochlorococcus contribute significantly to primary production in the subtropical North Pacific Ocean. Given its relatively low contribution to community biomass (Campbell et al. 1994), Synechococcus does not significantly contribute to the total primary production at Station ALOHA (Table 3).

The carbon/cell conversion factor may also affect the accuracy of the estimation of primary production. The conversion factors we used in this paper were based on

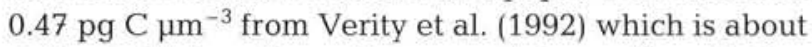
4 times higher than those used in earlier studies (Glover et al. 1988). Also, the size of Prochlorococcus 
cells is smaller in near-surface waters and increases with depth (Campbell et al. 1994), as does Synechococcus (Olson et al. 1990b, Burkill et al. 1993).

The contribution of Prochlorococcus to total primary production is higher in surface water. At the chlorophyll maximum layer, which varies between 100 and $120 \mathrm{~m}$, the contribution from picoeukaryotes becomes more important as shown in cell abundance (Fig. 7a) and biomass (Campbell et al. 1994). Our method is inappropriate for eukaryotic algae. Results from dilution experiments at Station ALOHA showed that the algae grew faster than Prochlorococcus and Synechococcus (data not shown) and they should certainly contribute significantly more to primary production than Synechococcus.

Because Prochlorococcus is a dominant component of the phytoplankton community in the tropical and subtropical open-ocean ecosystems, understanding its contribution to photosynthetic biomass and primary production in the global oceans is relevant to elucidating the dynamics of pelagic marine food webs. The implications of these results are important with regard to issues such as global ocean flux. We have demonstrated the effectiveness of kanamycin use in the selective inhibitor technique. In using this approach together with flow cytometric enumeration, we estimate that the contribution of Prochlorococcus to primary production in the North Pacific is approximately 1 order of magnitude greater than that of Synechococcus.

Acknowledgements. We thank D. M. Karl, C. D. Winn, D. V. Hebel, R. M. Letelier and L. Tupas of JGOFS HOT program for their continued support for our field experiments at Station ALOHA, and H. A. Nolla for assistance in flow cytometric analyses. We also thank R. R. Bidigare and D. Vaulot for helpful comments on the manuscript. Support for this project is from National Science Foundation grants OCE 90-15883 and 93-15432. This is contribution no. 3682 from the School of Ocean and Earth Science and Technology, University of Hawaii.

\section{LITERATURE CITED}

Armbrust, E. V., Bowen, J. D., Olson, R. J., Chisholm, S. W. (1989). Effect of light on the cell cycle of a marine Synechococcus strain. Appl. environ. Microbiol. 55: 425-432

Azam, F., Fenchel, T., Field, J. G., Gray, J. S., Meyer-Reil, L. A., Thingstad, F. (1983). The ecological role of watercolumn microbes in the sea. Mar. Ecol. Prog. Ser. 10: $257-263$

Burkill, P. H., Leakey, R. J. G., Owens, N. J. P., Mantoura, R. F. C. (1993). Synechococcus and its importance to the microbial foodweb of the northwestern Indian Ocean. Deep Sea Res. II 40: 773-782

Campbell, L., Carpenter, E. J. (1986a). Diel patterns of cell division in marine Synechococcus spp. (Cyanobacteria): use of the frequency of dividing cells technique to measure growth rate. Mar. Ecol. Prog. Ser. 32: 139-148
Campbell, L., Carpenter, E. J. (1986b). Estimating the grazing pressure of heterotrophic nanoplankton on Synechococcus spp. using the sea water dilution and selective inhibitor techniques. Mar. Ecol. Prog. Ser. 33: 121-129

Campbell, L., Nolla, H. A., Vaulot, D. (1994). The importance of Prochlorococcus to community structure in the central North Pacific Ocean. Limnol. Oceanogr. 39: 954-961

Campbell, L., Vaulot, D. (1993). Photosynthetic picoplankton community structure in the subtropical North Pacific Ocean near Hawaii (Station ALOHA). Deep Sea Res. 40: 2043-2060

Carpenter, E. J., Chang, J. (1988). Species-specific phytoplankton growth rates via diel DNA synthesis cycles. I. Concept of the method. Mar. Ecol. Prog. Ser. 43: 105-111

Chavez, F. P., Buck, K., Coale, K., Martin, J. H., Ditullio, G. R., Welschmeyer, N. A. (1991). Growth rates, grazing, sinking and iron limitation of equatorial Pacific phytoplankton. Limnol. Oceanogr. 36: 1816-1833

Chisholm, S. W., Olson, R. J., Zettler, E. R., Goericke, R, Waterbury, J. B., Welschmeyer, N. A. (1988). A novel freeliving prochlorophyte abundant in the oceanic euphotic zone. Nature 334: 340-343

Fuhrman, J. A., McManus, G. B. (1984). Do bacteria-sized marine eukaryotes consume significant bacterial production? Science 224: 1257-1260

Furnas, M. J. (1990). In situ growth rates of marine phytoplankton: approaches to measurement, community and species growth rates. J. Plankton Res. 12: 1117-1151

Gieskes, W. W. C., Kraay, G. W. (1989). Estimating the carbon-specific growth rate of the major algal species groups in eastern Indonesian waters by ${ }^{14} \mathrm{C}$ labeling of taxonspecific carotenoid. Deep Sea Res. 36: 1127-1139

Glover, H. E. (1985). The physiology and ecology of the marine cyanobacterial genus Synechococcus. Adv. aquat. Microbiol, 3: 49-107

Glover, H. E., Prézelin, B. B., Campbell, L., Wyman, M., Garside, C. (1988). A nitrate-dependent Synechococcus bloom in surface Sargasso Sea water. Nature 331: 161-163

Goericke, R., Welschmeyer, N. A. (1993). The marine prochlorophyte Prochlorococcus contributes significantly to phytoplankton biomass and primary production in the Sargasso Sea. Deep Sea Res. 40; 2283-2294

Greenwood, D. (1989). Inhibitors of bacterial protein synthesis. In: Greenwood, D. (ed.) Antimicrobial chemotherapy. Oxford University Press, New York, p. 32-45

Herbland, A., Le Bouteiller, A., Raimbault, P. (1985). Size structure of phytoplankton biomass in the equatorial Atlantic Ocean. Deep Sea Res. 32: 819-836

Iturriaga, R., Marra, J. (1988). Temporal and spatial variability of chroococcoid cyanobacteria Synechococcus spp. specific growth rates and their contribution to primary production in the Sargasso Sea. Mar. Ecol. Prog. Ser. 44: $175-181$

Iturriaga, R., Mitchell, B. G. (1986). Chrococcoid cyanobacteria: a significant component in the food web dynamics of the open ocean. Mar. Ecol. Prog. Ser. 28: 291-297

Johnson, P. W., Sieburth, J. M. (1979). Chroococcoid cyanobacteria in the sea: a ubiquitous and diverse phototrophic biomass. Limnol. Oceanogr, 24: 928-935

Landry, M. R., Hassett, R. P. (1982). Estimating the grazing impact of marine micro-zooplankton. Mar. Biol. 67: 283-288

Landry, M. R., Haas, L. W., Fagerness, V. L. (1984). Dynamics of microbial plankton communities: experiments in Kaneohe Bay, Hawaii. Mar. Ecol. Prog. Ser. 16: 127-133

Li, W. K. W., Subba Rao, D. V., Harrison, W. G., Smith, J. C., Cullen, J. J., Irwin, B., Platt, T. (1983). Autotrophic pico- 
plankton in the tropical ocean. Science 219: 292-295

Li, W. K., Wood, A. M. (1988). Vertical distribution of North Atlantic ultraphytoplankton: analysis by flow cytometry and epifluorescence microscopy. Deep Sea Res. 35: $1615-1638$

Monger, B. C., Landry, M. R. (1993). Flow cytometric analysis of marine bacteria with Hoechst 33342. Appl. environ. Microbiol. 59: 905-911

Newell, S. Y., Sherr, B. F., Sherr, E. B., Fallon, R. D. (1983). Bacterial response to the presence of eukaryotic inhibitors in water from a coastal marine environment. Mar. environ. Res. 10: 147-157

Olson, R. J., Chisholm, S. W., Zettler, E. R., Altabet, M. A., Dusenberry, J. A. (1990a). Spatial and temporal distributions of prochlorophyte picoplankton in the North Atlantic Ocean. Deep Sea Res. 37: 1033-1051

Olson, R. J., Chisholm, S. W., Zettler, E. R., Armbrust, E. V. (1990b). Pigments, size, and distribution of Synechococcus in the North Atlantic and Pacific Oceans. Limnol. Oceanogr. 35: 45-58

Pelczar, M. J., Reid, D., Chan, E. C. S. (1977). Microbiology. McGraw Hill, New York

Platt, T., Subba Rao, D. V., Irwin, B. (1983). Photosynthesis of picoplankton in the oligotrophic ocean. Nature 301: 702-704

Sherr, B. F., Sherr, E. B., Andrew, T. L., Fallon, R. D., Newell, S. Y. (1986). Trophic interactions between heterotrophic protozoa and bacterioplankton in estuarine water analyzed with selective metabolic inhibitors. Mar. Ecol. Prog. Ser. 32: 169-179

Sherr, B. F., Sherr, E. B., Fallon, R. D. (1987). Use of monodispersed, fluorescently labeled bacteria to estimate in situ protozoan bacterivory. Appl. environ. Microbiol. 53: 958-965

Sieburth, J. McN. (1984). Protozoan bacterivory in pelagic marine waters. In: Hobbie, J. E., Williams, P. J. leB. (eds.) Heterotrophic activity in the sea. Plenum Press, New York, p. 405-444

Takahashi, M., Bienfang, P. K. (1983). Size structure of phytoplankton biomass and photosynthesis in subtropical Hawaiian waters. Mar. Biol. 76: 203-211

This article was submitted to the editor
Thomas, W. H., Dodson, A. N. (1974). Inhibition of diatom photosynthesis by germanic acid: separation of diatom productivity from total marine primary productivity. Mar. Biol. 27: 11-19

Tupas, L., Santiago-Mandujano, F., Hebel, D., Lukas, R., Karl, D. M., Firing, E. (1994). Hawaii Ocean Time-series data report 5. School of Ocean and Earth Science and Technology Tech. Rep., Univ. Hawaii, Honolulu (in press)

Vaulot, D. (1989). CYTOPC: processing software for flow cytometric data. Signal Noise 2: 8

Vaulot, D., Courties, C., Partensky, F. (1989). A simple method to preserve oceanic phytoplankton for flow cytometric analysis. Cytometry 10: 629-635

Vaulot, D., Marie, D., Partensky, F., Olson, R. J., Chisholm, S. W. (1994). Prochlorococcus divides once a day at the Equator. (Abstract), In: 1994 Ocean Science Meeting. EOS, Trans. Am. Geophys. Union 75(3): 28

Vaulot, D., Partensky, F., Neveux, J., Mantoura, R. F. C., Llewellyn, C. (1990). Winter presence of prochlorophytes in surface waters of the northwestern Mediterranean Sea. Limnol. Oceanogr. 35: 1156-1164

Veldhuis, M. J. W., Kraay, G. W., Gieskes, W. W. C. (1993). Growth and fluorescence characteristics of ultraplankton on a north-south transect in the eastern North Atlantic. Deep Sea Res. II 40: 609-626

Veldhuis, M. J. W., Kraay, G. W. (1993). Cell abundance and fluorescence of picoplankton in relation to growth irradiance and nitrogen availability in the Red Sea. Neth. J. Sea Res. 31: 135-145

Verity, P. G., Robertson, C. Y., Tronzo, C. R., Andrews, M. G., Nelson, J. R., Sieracki, M. E. (1992). Relationships between cell volume and the carbon and nitrogen content of marine photosynthetic nanoplankton. Limnol. Oceanogr. 37: $1434-1446$

Waterbury, J. B., Watson, S. W., Guillard, R. R. L., Brand, L. E. (1979). Widespread occurrence of a unicellular, marine, planktonic cyanobacterium. Nature 277: 293-294

Waterbury, J. B., Watson, S. W., Valois, F. W., Franks, D. G. (1986). Biological and ecological characterization of the marine unicellular cyanobacteria Synechococcus. Can. Bull. Fish. Aquat. Sci. 214: 71-120

Manuscript first received: April 27, 1994

Revised version accepted: September 29, 1994 